\title{
Energy consumption, real GDP, and financial development nexus in Italy: an application of an auto-regressive distributed lag bound testing approach
}

\author{
C. Magazzino \\ Department of Political Sciences, Roma Tre University, Italy
}

\begin{abstract}
This study aims to explore the relationship among energy consumption, real income, financial development, and oil prices in Italy over the period 1960-2014. The results of unit root and stationarity tests show that the variables are nonstationary at levels, but stationary in first-differences form, or I(1). The ARDL bounds F-test reveals an evidence of a long-run relationship among the four variables at $1 \%$ significance level. The results show that an increase in real GDP and oil prices have a significant effect on energy consumption in the long-run. The coefficients of estimated ECT are also negative and statistically significant. In addition, the paper explores the causal relationship among the variables by using a VAR framework, with Toda and Yamamoto but also Granger causality tests, within both multivariate and bivariate systems. The findings indicate that energy consumption is affected by real GDP.
\end{abstract}

Keywords: financial development, energy consumption, GDP, ARDL, Italy, JEL classification: B22, C32, N54, Q43.

\section{Introduction}

Italy has some indigenous production of oil and natural gas, but both oil and gas production will progressively decline in the coming years. In 2012, Italy's total domestic oil production met only $7.7 \%$ of its domestic demand. Italy relies heavily on imports and is the world's largest net importer of electricity (Magazzino [1]). In 2011, 47.5 billion $\mathrm{kWh}$ was imported, and only 1.8 billion $\mathrm{kWh}$ exported, this net import level being typical of the last decade. As of 2011, the transport sector 
contributed most to Italy's final energy consumption, with $30.4 \%$, with the residential (24.8\%) and industrial $(22.8 \%)$ also contributing significantly. Thus, it should be clear why it is crucial for Italy to analyse the relationship amongst energy consumption, financial development, and real income (Magazzino [2]).

The nexus between economic growth and financial development, as well as energy consumption and economic growth, has been the subject of intense research in the last decades. Nevertheless, the empirical evidence remains controversial and ambiguous. Although several papers examine the relationship among energy consumption, economic growth and financial development, few studies concern Italy.

In the present paper, the relationship among real GDP, energy consumption and financial development in Italy has been investigated for the period 1960-2014, using time series methodologies. The results might help to define and implement the appropriate energy development policies in Italy.

Different econometric techniques - such as the General Methods of Moment (GMM) or the Auto-Regressive Distributed Lags (ARDL) bounds test - are usually employed in the empirical analysis. Our study also filled the literature gap of applying ARDL technique to examine this relevant issue for Italy.

Besides the Introduction, the outline of this paper proceeds as follows. Section 2 provides a survey of the economic literature on the nexus among energy consumption, real income, and financial development. Section 3 contains an overview of the applied empirical methodology and a brief discussion of the data used. Section 4 discusses our empirical results. Finally, Section 5 presents some concluding remarks and policy implications.

\section{Literature review}

The relationship between financial development and energy consumption has newly started to be discussed in energy economics literature (Çoban and Topcu [3]). As shown in the survey of the literature presented below, both time series and panel data studies have been published in the last decade.

As concerns time series studies, Ali et al. [4], using an ARDL bounds test framework, analysed the dynamics of financial development, economic growth, energy prices and energy consumption in Nigeria for the period of 1972Q12011Q4. The results show that in the short-run financial development has significant negative impact on fossil fuel consumption. However, energy prices have positive and significant influence on the consumption of fossil fuel. Mahalik and Mallick [5] investigated the relationship between energy consumption, economic growth and financial development in India using annual data for the period 1971-2009. The ARDL approach suggest that energy consumption is positively and significantly affected by proportion of urban population in total population, while the same is negatively and significantly impacted by financial development, economic growth and proportion of industrial output in total output. Salman and Atya [6] test the causality flow among financial development, economic growth and energy consumption in Algeria, Egypt, and Tunisia. The results are mixed. The study of Abalaba and Dada [7] analysed the relationship 
among energy consumption, real output, financial development, monetary policy rate and consumer prices, providing weak evidence in support of long-run relationship between energy consumption and economic growth. Moreover, energy consumption positively influenced output growth in the short-run. Islam et al. [8] studied the relationship among Financial development, energy consumption and GDP in Malaysia, covering the 1971-2009 years. The results suggest that energy consumption is influenced by economic growth and financial development, both in the short and the long run, but the population-energy relation holds only in the long run. Ozturk and Acaravci [9] examined the causal relationship among financial development, trade, economic growth, energy consumption and carbon emissions in Turkey for the 1960-2007 period. The bounds test yields evidence of a long-run relationship among per capita carbon emissions, per capita energy consumption, per capita real income, the square of per capita real income, openness and financial development. Jalil and Feridun [10] investigated the impact of financial development, economic growth and energy consumption on environmental pollution in China from 1953 to 2006, using the ARDL bounds testing procedure. The results of the analysis reveal a negative sign for the coefficient of financial development, suggesting that financial development in China has not taken place at the expense of environmental pollution. On the contrary, financial development has led to a decrease in environmental pollution. Farhani and Ozturk [11] examined the causal relationship among $\mathrm{CO}_{2}$ emissions, real GDP, energy consumption, financial development, trade openness, and urbanization in Tunisia over the period of 1971-2012. The results reveal a positive sign for the coefficient of financial development, suggesting that the financial development in Tunisia has taken place at the expense of environmental pollution, with a positive monotonic relationship between real GDP and $\mathrm{CO}_{2}$ emissions.

With regard to panel data analyses, Chang [12] analysed the nonlinear effects of financial development and income on energy consumption in a sample of 53 countries for the period 1999-2008. It emerges a single-threshold effect on energy consumption when private credit, domestic credit, value of traded stocks, and stock market turnover are used as financial development indicators. Zeren et al. [13] analysed 7 newly industrialized countries, over the period 1971-2010, reaching mixed results. Sadorsky [14] examined the impact of financial development on energy consumption in a sample of 9 Central and Eastern European frontier economies. The empirical results show a positive relationship between financial development and energy consumption. Çoban and Topcu [3] investigated the financial development-energy consumption nexus in the EU over the period 1990-2011 by using system-GMM model. No significant relationship is found in the EU-27. The empirical results, however, provide strong evidence of the impact of the financial development on energy consumption in the old members. Shahbaz et al. [15] examined the linkages among economic growth, energy consumption, financial development, trade openness and $\mathrm{CO}_{2}$ emissions over the period 1975Q1-2011Q4 for Indonesia. The results indicate that economic growth and energy consumption increase emissions, while financial development and trade openness compact it. Shahbaz et al. [16] investigated the relationship between energy use and economic growth in the case of China over the 1971-2011 
years. The ARDL bounds testing approach showed that energy use, financial development, capital, exports, imports and international trade have positive impact on economic growth. The Granger causality analysis revealed that unidirectional causal relationship running from energy use to economic growth. Financial development and energy use Granger cause each other. Al-mulali and Sab [17] explored the impact of energy consumption and $\mathrm{CO}_{2}$ emission on the economic and financial development in 19 countries in the period 1980-2008. The empirical findings show that energy consumption enables these countries to achieve high economic and financial development. However, the high development that these countries have achieved in the late three decades increased the $\mathrm{CO}_{2}$ emission. A related study was conducted by Al-mulali and Sab [18], where the impact of energy consumption and $\mathrm{CO}_{2}$ emission on GDP growth and financial development in thirty Sub Saharan African Countries was investigated, from 1980 to 2008. The results indicate that energy consumption had played an important role to increase both economic growth and the financial development in those economies, although with the consequence of high pollution. Shahbaz and Lean [19] assessed the relationship among energy consumption, financial development, economic growth, industrialization and urbanization in Tunisia from 1971 to 2008. The ARDL bounds testing approach results confirm the existence of long-run relationship among energy consumption, economic growth, financial development, industrialization and urbanization in Tunisia. Sadorsky [20], using a GMM estimation techniques explored the impact of financial development on energy consumption in a sample of 22 emerging countries, in the years 1990-2006. The empirical results show a positive and statistically significant relationship between financial development and energy consumption.

As regards study on the Italian case, Lee and Chien [21] studied the dynamic linkages among energy consumption, capital stock, and real income in G-7 countries. A unidirectional relationship running from energy consumption to real income was observed. Chontanawat et al. [22] tested for causality between energy and GDP using a dataset of $30 \mathrm{OECD}$ and 78 non-OECD countries. For Italy they showed evidence of causality from energy to GDP. Zachariadis [23] applied bivariate energy use-economic growth causality tests for G-7 countries. Bidirectional Granger-causality emerges for most sectors. Lee [29] explored the causality relationship between energy consumption and GDP in G-11 countries. The results indicate that unidirectional causality running from GDP to energy consumption exists in Italy. Soytas and Sari [24] analysed the relationship between energy consumption and income in G-7 countries. For Italy they found that causality seems to run both ways. Soytas and Sari [25] investigated the time series properties of energy consumption and GDP in 10 emerging markets and G-7 countries. Causality running from GDP to energy consumption was discovered for Italy.

In our analysis the log transformations of the variables have been derived. The empirical analysis uses the time series data of the fossil fuel energy consumption ( $\%$ of total, EC), domestic credit to private sector (\% of GDP, $F D$ ), real per capita GDP (2011 US dollars per capita, $R G D P$ ), and oil price (dollars per barrel, $O P$ ) for Italy in the period 1960-2014. The data are obtained from the World 
Development Indicator (WDI). The choice of the starting period was constrained by domestic credit to private sector data availability.

A visual inspection of the series in logarithmic form shows that there is an upward trend for real aggregate income and oil prices.

Some descriptive statistics are summarized in Table 2 as a preliminary analysis. The mean value of our four variables is positive. Moreover, financial development has positive value of skewness, indicating that the distribution is skewed to the right.

Table 1: Exploratory data analysis.

\begin{tabular}{|c|c|c|c|c|c|c|c|c|}
\hline Variable & Mean & Median & $\begin{array}{c}\text { Standard } \\
\text { deviation }\end{array}$ & Skewness & Kurtosis & Range & IQR & $\begin{array}{c}10- \\
\text { Trim }\end{array}$ \\
\hline EC & 4.5140 & 4.5237 & 0.0309 & -1.8793 & 6.5356 & 0.1531 & 0.0288 & 4.520 \\
\hline RGDP & 10.0188 & 10.1003 & 0.3701 & -0.6723 & 2.2310 & 1.2475 & 0.5951 & 10.060 \\
\hline FD & 4.1332 & 4.0801 & 0.1992 & 0.6364 & 2.4412 & 0.6983 & 0.2585 & 4.114 \\
\hline OP & 2.7479 & 2.9576 & 1.1033 & -0.2802 & 2.0159 & 3.5293 & 2.0602 & 2.788 \\
\hline
\end{tabular}

Sources: our calculations on WDI data.

The energy consumption is statistically positively correlated with real GDP $(r=0.42)$, and negatively with financial development $(r=-0.61)$, while oil prices variable is statistically negatively correlated with real income $(r=-0.66)$. In addition, these results are broadly confirmed by cross correlations analysis.

\section{Empirical results}

As can be grasped by a visual inspection, the four analyzed series do not seem to have stationary properties in the levels, contrarily to the relative first differences. Table 2 contains the results of common unit root and stationarity tests, to determine the order of integration of our variables. Here, we applied four different tests: in general, they indicate that energy consumption, real GDP, financial development and oil prices are all non-stationary at levels, but stationary at first differences.

In fact, for all series we reject the hypothesis of non-stationarity at the 5\% level of significance, both with constant and constant plus trend deterministic specification. We therefore can conclude that all our series are integrated of order one, or I(1). The lag-order selection has been chosen according to the Akaike's information criterion (AIC), the Schwarz's Bayesian information criterion (SBIC), and the Hannan-Quinn information criterion (HQIC).

The bounds $F$-test for cointegration yields evidence of a long-run relationship among energy consumption, real income, financial development, and oil prices at $1 \%$ significance level.

The long-run elasticity estimates of energy consumption with respect to economic growth is $\beta_{1}>0$, at $1 \%$ significance level, in line with previous findings in Shahbaz et al. [16], but in contrast to Mahalik and Mallick [5]. This means as per capita real income increases, per capita energy consumption increase as well. Moreover, it implies that energy demand plays a relevant role to enhance economic growth in Italy. Financial development variable has no significant effect on energy 
consumption in the long-run. This result is similar to Ali et al. [4]. Oil prices are negative and significant at $1 \%$, which means that a $1 \%$ increase in oil prices could trigger consumption of energy to decrease by $0.32 \%$, therefore an increase in oil prices leads to an increase in the cost of energy as well as a reduction in energy consumption in Italy in the long-run.

Table 2: $\quad$ Results for unit roots and stationarity tests.

\begin{tabular}{|c|c|c|c|c|c|}
\hline \multirow{2}{*}{ Variable } & \multicolumn{5}{|c|}{ Unit root and stationarity tests } \\
\cline { 2 - 6 } & $\begin{array}{c}\text { Deterministic } \\
\text { component }\end{array}$ & ADF & ERS & PP & \\
\hline EC & constant & 0.2641 & -0.3642 & -0.1378 & $0.3477^{*}$ \\
\hline RGDP & constant & $-5.7760^{* * *}$ & -1.1587 & $-6.1585^{* * *}$ & $0.9246^{* * *}$ \\
\hline FD & constant & -1.1517 & -1.0798 & -0.7128 & $0.3472^{*}$ \\
\hline OP & constant & -0.6667 & 0.3815 & -0.6606 & $0.8163^{* * *}$ \\
\hline EC & constant, trend & 1.2620 & 0.3399 & -0.0891 & $0.2171^{* * *}$ \\
\hline RGDP & constant, trend & -0.4072 & -0.1110 & 0.0730 & $0.2473^{* * *}$ \\
\hline FD & constant, trend & -1.4320 & -1.5342 & -1.0398 & $0.2006^{* *}$ \\
\hline OP & constant, trend & -1.7670 & -1.8064 & -1.8837 & $0.1199^{*}$ \\
\hline$\Delta$ EC & constant & -2.4261 & 0.4450 & $-4.4619^{* * *}$ & $0.7296^{* *}$ \\
\hline$\Delta$ RGDP & constant & $-4.7346^{* * *}$ & 1.0069 & $-4.7167^{* * *}$ & $0.9610^{* * *}$ \\
\hline$\Delta$ FD & constant & $-2.8399^{*}$ & $-2.7733^{* * *}$ & $-3.4928^{* *}$ & 0.1880 \\
\hline$\Delta$ OP & constant & $-7.0112^{* * *}$ & $-6.9330^{* * *}$ & $-7.0111^{* * *}$ & 0.0816 \\
\hline$\Delta$ EC & constant, trend & $-3.6601^{* *}$ & $-2.9090^{*}$ & $-6.2580^{* * *}$ & $0.1309^{*}$ \\
\hline$\Delta$ RGDP & constant, trend & $-6.0832^{* * *}$ & $-6.4744^{* * *}$ & $-7.9507^{* * *}$ & 0.1063 \\
\hline$\Delta$ FD & constant, trend & $-3.5391^{* *}$ & $-2.9500^{*}$ & $-3.4808^{*}$ & 0.1047 \\
\hline$\Delta$ OP & constant, trend & -6.9387 & $-7.0560^{* * *}$ & -6.9385 & 0.0832 \\
\hline
\end{tabular}

Notes: the tests are performed on the log-levels of the variables. ADF, ERS, PP, and KPSS refers respectively to the Augmented Dickey-Fuller test, the Elliot, Rothenberg, and Stock point optimal test, the Phillips-Perron test, and the Kwiatkowski, Phillips, Schmidt, and Shin test. When it is required, the lag length is chosen according to the HQIC. ${ }^{* * *} p<0.01,{ }^{* *} p<0.05,{ }^{*} p<0.10$.

Table 3: ARDL bound test estimation results.

\begin{tabular}{|c|c|c|c|c|c|}
\hline \multirow{2}{*}{$\begin{array}{c}\text { Model for } \\
\text { estimation }\end{array}$} & \multirow{2}{*}{$\begin{array}{c}\text { Lag } \\
\text { length }\end{array}$} & $F$-statistics & \multirow{2}{*}{$\begin{array}{c}\text { Significance } \\
\text { level }\end{array}$} & \multicolumn{2}{|c|}{ Critical bound } \\
\cline { 5 - 6 } & & & & \multicolumn{2}{|c|}{$F$-statistics } \\
\hline$F_{E C}^{R G D P, F D, O P}$ & 2 & $8.1949^{*} * *$ & 1 & $I(0)$ & $I(1)$ \\
\hline & & & 5 & 2.65 & 4.66 \\
\hline & & & 10 & 2.37 & 3.67 \\
\hline
\end{tabular}

Notes: Asymptotic critical value bounds are obtained from table $F$-statistic in Pesaran et al. [30]. $* * * p<0.01, * * p<0.05, * p<0.10$.

Table 4: Long-run coefficients estimation.

\begin{tabular}{|c|c|c|}
\hline Regressors & Coefficient & Standard error \\
\hline RGDP & 0.5074 & $0.1776^{* * *}$ \\
\hline FD & -0.6340 & 1.1532 \\
\hline OP & -0.3183 & $0.1123 * * *$ \\
\hline Constant & 2.6088 & $0.7637 * * *$ \\
\hline
\end{tabular}

Notes: $* * * p<0.01, * * p<0.05, * p<0.10$. 
The coefficients of the estimated Error Correction Term (ECT) are also negative and statistically significant at $1 \%$ confidence level. These values indicate that any deviation from the long-run equilibrium between variables is corrected for each period to return the long-run equilibrium level.

In addition, due to the structural changes in Italian economy - especially during the eighties (Magazzino [26, 27]) - it is likely that macroeconomic series may be subject to one or multiple structural breaks. For this purpose, the stability of the short-run and long-run coefficients are checked through the cumulative sum (CUSUM) and cumulative sum of squares (CUSUMSQ) tests proposed by Brown et al. [28]. Unlike Chow test, requires break point(s) to be specified, the CUSUM and CUSUMSQ tests are quite general tests for structural change in that they do not require a prior determination of where the structural break takes place. The plot of CUSUM and CUSUMSQ tests statistics fall inside the critical bounds of $5 \%$ significance. This implies that the estimated parameters are stable over the periods.

Table 5: $\quad$ Estimated short-run coefficients from ECM.

\begin{tabular}{|c|c|c|}
\hline Regressors & Coefficient & Standard error \\
\hline$\Delta \mathrm{EC}_{\mathrm{t}-1}$ & 0.2530 & $0.1220^{* *}$ \\
\hline$\Delta \mathrm{RGDP}$ & 0.1638 & $0.0292^{* * *}$ \\
\hline$\Delta \mathrm{FD}$ & -0.0108 & 0.0193 \\
\hline$\Delta \mathrm{OP}$ & -0.0284 & 0.0337 \\
\hline $\mathrm{ECM}_{\mathrm{t}-1}$ & -0.0166 & $0.0026^{* * *}$ \\
\hline
\end{tabular}

Notes: $* * * p<0.01, * * p<0.05, * p<0.10$.

Table 6 presents the estimated ARDL model that has passed several diagnostic tests, which indicate no evidence of non-normality, serial correlation, heteroscedasticity, and autoregressive conditional heteroscedasticity.

Table 6: ARDL diagnostic tests results.

\begin{tabular}{|c|c|c|}
\hline Test statistics & $L M$ version & $F$ version \\
\hline 1: Serial correlation & $\chi^{2}=0.6438(0.7248)$ & $0.2663(0.7676)$ \\
\hline 2: Functional form & & $11.1963(0.0018) * * *$ \\
\hline 3: Normality & $3.5866(0.1664)$ & \\
\hline 4: Heteroscedasticity & $0.9105(0.4968)$ & $5.6398(0.4647)$ \\
\hline 5: ARCH & $0.0785(0.7806)$ & $0.0818(0.7749)$ \\
\hline
\end{tabular}

Notes: 1: Lagrange-Multiplier test of residual serial correlation; 2: Ramsey's RESET test using squared of the fitted values; 3: Jarque-Bera test for normality; 4: Breusch-Pagan-Godfrey heteroscedasticity test; 5: AutoRegressive Conditional Heteroscedasticity test. $* * * p<0.01$, $* * p<0.05, * p<0.10$.

Granger causality tests following the Toda and Yamamoto approach requires the estimation of an augmented $\operatorname{VAR}(k+d)$ model, where $k$ is the optimal lag 
length and $d$ is the order of integration of the series. For the multivariate specification, all tests suggest the inclusion of one lag in a VAR model and thus $k=1$; hence, the final model to be estimated is VAR(2). To ensure that the VAR model is well specified and does not suffer from any normality or serial correlation problems, additional tests are carried out. Although the results are not reported to save space, diagnostic tests suggest the general absence of problems in the estimated VAR(2) model, with regard to normality and autocorrelation in the residuals, stability condition, and lag-exclusion.

The results of Toda and Yamamoto Granger non-causality tests are presented in Table 7. If we want to reject the null hypothesis of " $X$ does not Granger cause $Y$ ' at a $5 \%$ level of significance, then the $P$-Value should be less than 0.05 . The left column in the table represents the dependent variable, whilst variables listed in the row are the independent variables (source of causation). In order to provide robust conclusions, both multivariate and bivariate tests are considered. For the multivariate model, empirical findings show that energy consumption is driven by financial development and oil prices. In addition, financial development is caused by energy consumption, too. The bivariate system exhibits a unidirectional causality flow running from real income to energy. This is in line with the findings of Lee [29], and Soytas and Sari [25]. However, it is interesting to note that the bivariate results roughly confirm the previous of the multivariate system. In fact, again, energy consumption is caused by financial development and oil prices, while oil prices are sensible to financial development.

Furthermore, the results of the standard Granger causality tests are similar to those obtained via the Toda and Yamamoto approach. They indicate that energy consumption is affected by real GDP, both in the multivariate tests and in the bivariate ones. Again, in the bivariate system, real income is driven by financial development and oil prices.

\section{Concluding remarks and policy implications}

This study has extended the research on the causal relationship among energy consumption, real income, and financial development using annual data for Italy in the 1960-2014 years. The results of unit root tests reveal that all variables are integrated of order one, $I(1)$, since each of them is non-stationary in its level form, and stationary in first differences. The ARDL bounds $F$-test evidences the existence of a long-run relationship among energy consumption, real income, financial development, and oil prices at 1\% significance level. The long-run coefficients estimation results show that an increase in real GDP and oil prices have a significant effect on energy consumption, although with an opposite sign. Moreover, the coefficients of estimated ECT are also negative and statistically significant. Finally, causality analysis in general reveal that energy consumption is driven by real income, financial development, and oil prices. 


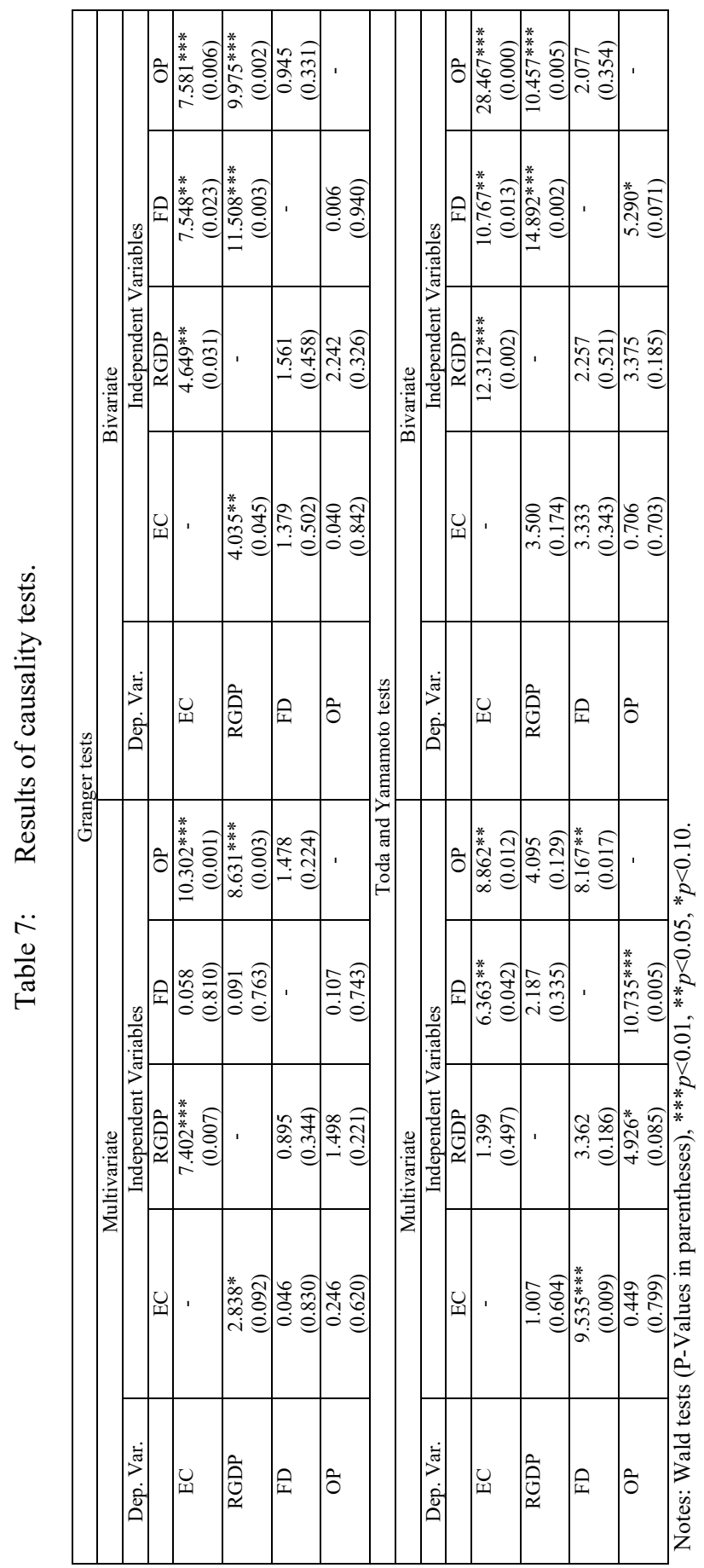


Causality analyses indicate that a unidirectional causality running from real income to energy exists, in line with "conservation hypothesis". This means that continuous economic growth simultaneously generates a continuous rise in energy consumption, and the policy of conserving energy consumption may be implemented with little or no adverse effect on economic growth, such as in a less energy-dependent economy. In this case, energy consumption is fundamentally driven by income, and as such, taking measures to conserve energy may be feasible without compromising economic growth. Beyond this, it is implied that a strategy for sustainable development with a lower level of $\mathrm{CO}_{2}$ emissions may, indeed, be appropriate in Italy (Magazzino [27]).

\section{Appendix}

Table A: Correlation matrix.

\begin{tabular}{|c|c|c|c|c|}
\hline & $E C$ & $R G D P$ & $F D$ & $O P$ \\
\hline EC & 1.000 & $0.4198^{* *}$ & $-0.6135^{* * *}$ & -0.1882 \\
\hline RGDP & $0.4198^{* *}$ & 1.0000 & $-0.3908^{* *}$ & $-0.6601^{* * *}$ \\
\hline FD & $-0.6135^{* * *}$ & $-0.3908^{* *}$ & 1.0000 & 0.2522 \\
\hline OP & -0.1882 & $-0.6601^{* * *}$ & 0.2522 & 1.0000 \\
\hline
\end{tabular}

Notes: Sidak's correction applied, $* * * p<0.01, * * p<0.05,{ }^{*} p<0.10$.

\section{References}

[1] Magazzino, C. Electricity Demand, GDP and Employment: Evidence from Italy. Frontiers in Energy, 8(1), pp. 31-40, 2014a.

[2] Magazzino, C. On the Relationship between Disaggregated Energy Production and GDP in Italy, Energy \& Environment, 23(8), pp. 11911207, 2012.

[3] Çoban, S. \& Topcu, M. The nexus between financial development and energy consumption in the EU: A dynamic panel data analysis. Energy Economics, 39, pp. 81-88, 2013.

[4] Ali, H.S., Yusop, Z.B. \& Hook, L.S. Financial Development and Energy Consumption Nexus in Nigeria: An Application of Autoregressive Distributed Lag Bound Testing Approach. International Journal of Energy Economics and Policy, 5(3), pp. 816-821, 2015.

[5] Mahalik, M.K. \& Mallick, M.H. Energy Consumption, Economic Growth and Financial Development: Exploring the Empirical Linkages for India. The Journal of Developing Areas, 48(4), pp. 139-159, 2014.

[6] Salman, D.M. \& Atya, E.M. What is the role of Financial Development and Energy Consumption on Economic Growth? New Evidence from North African Countries. International Journal of Finance \& Banking Studies. 3(1), pp. 137-149, 2014.

[7] Abalaba, B.P. \& Dada, M.A. Energy Consumption and Economic Growth Nexus: New Empirical Evidence from Nigeria. International Journal of Energy Economics and Policy, 3(4), pp. 412-423, 2013. 
[8] Islam, F., Shahbaz, M., Ahmed, A.U. \& Alam, M.M. Financial development and energy consumption nexus in Malaysia: A multivariate time series analysis. Economic Modelling, 30, pp. 435-441, 2013.

[9] Ozturk, I. \& Acaravci, A. The long-run and causal analysis of energy, growth, openness and financial development on carbon emissions in Turkey. Energy Economics, 36, pp. 262-267, 2013.

[10] Jalil, A. \& Feridun, M. The impact of growth, energy and financial development on the environment in China: A cointegration analysis. Energy Economics, 33, pp. 284-291, 2011.

[11] Farhani, S. \& Ozturk, I. Causal relationship between $\mathrm{CO}_{2}$ emissions, real GDP, energy consumption, financial development, trade openness, and urbanization in Tunisia. Environmental Science and Pollution Research, 22, pp. 15663-15676, 2015.

[12] Chang, S.C. Effects of financial developments and income on energy consumption. International Review of Economics and Finance, 35, pp. 2844, 2015.

[13] Zeren, F., Koc, M., \& Konuk, F. Interaction between Finance, Tourism and Advertising: Evidence from Turkey. Tourism \& Hospitality Management, 20(2), pp. 185-193, 2014.

[14] Sadorsky, P. Financial development and energy consumption in Central and Eastern European frontier economies. Energy Policy, 39, pp. 999-1006, 2011.

[15] Shahbaz, M., Hye, Q.M.A., Tiwari, A.K. \& Leitão, N.C. Economic growth, energy consumption, financial development, international trade and $\mathrm{CO}_{2}$ emissions in Indonesia. Renewable and Sustainable Energy Reviews, 25, pp. 109-121, 2013a.

[16] Shahbaz, M., Khan, S. \& Tahir, M.I. The dynamic links between energy consumption, economic growth, financial development and trade in China: Fresh evidence from multivariate framework analysis. Energy Economics, 40, pp. 8-21, 2013b.

[17] Al-mulali, U. \& Sab, C.N.B.C. The impact of energy consumption and $\mathrm{CO}_{2}$ emission on the economic and financial development in 19 selected countries. Renewable and Sustainable Energy Reviews, 16, pp. 4365-4369, 2012a.

[18] Al-mulali, U. \& Sab, C.N.B.C. The impact of energy consumption and $\mathrm{CO}_{2}$ emission on the economic growth and financial development in the Sub Saharan African countries. Energy, 39, pp. 180-186, 2012 b.

[19] Shahbaz M., Lean H.H. (2012). Does financial development increase energy consumption? The role of industrialization and urbanization in Tunisia. Energy Policy, 40, pp. 473-479.

[20] Sadorsky, P. The impact of financial development on energy consumption in emerging economies. Energy Policy, 38, pp. 2528-2535, 2010.

[21] Lee, C.C. \& Chien, M.S. Dynamic modelling of energy consumption, capital stock, and real income in G-7 countries. Energy Economics, 32, pp. 564-581, 2010. 
32 Energy Production and Management in the 21st Century II

[22] Chontanawat, J., Hunt, L.C. \& Pierse, R. Does energy consumption cause economic growth?: Evidence from a systematic study. Journal of Policy Modeling, 30, pp. 209-220, 2008.

[23] Zachariadis, T. Exploring the relationship between energy use and economic growth with bivariate models: New evidence from G-7 countries. Energy Economics, 29, pp. 1233-1253, 2007.

[24] Soytas, U. \& Sari, R. Energy consumption and income in G-7 countries. Journal of Policy Modeling, 28, pp. 739-750, 2006.

[25] Soytas, U. \& Sari, R. Energy consumption and GDP: causality relationship in G-7 countries and emerging markets. Energy Economics, 25, pp. 33-37, 2003.

[26] Magazzino, C. Energy Consumption and GDP in Italy: cointegration and causality analysis. Environment, Development and Sustainability, 16(2), 2014b.

[27] Magazzino, C. The relationship between $\mathrm{CO}_{2}$ emissions, energy consumption and economic growth in Italy, International Journal of Sustainable Energy, 2014c.

[28] Brown, R.L., Durbin, J. \& Evans, J.M. Techniques for testing the consistency of regression relations over time. Journal of Royal Statistical Society, 37, pp. 149-192, 1975.

[29] Lee, C.C. The causality relationship between energy consumption and GDP in G-11 countries revisited. Energy Policy, 34, pp. 1086-1093, 2006.

[30] Pesaran, H.M., Shin, Y. \& Smith, R.J. Bounds testing approaches to the analysis of level relationships, Journal of Applied Econometrics, 16, pp. 289-326, 2001. 